\title{
Determinan Biaya Utang Perusahaan Otomotif dan Produk Komponen Tahun 2014-2019
}

\author{
(Determinants of Cost of Debt for Automotive and Component Products Companies in 2014-2019) \\ Destia Rahmatu Jannah ${ }^{1 *}$, Dewi Purwanti ${ }^{2}$ \\ ${ }^{1,2}$ Politeknik Statistika STIS \\ Perumahan Sumbersari Permai 1 Blok W/8, Kranjingan, Sumbersari, Jember, Jawa Timur 68126 \\ E-mail: 211709614@stis.ac.id
}

\begin{abstract}
ABSTRAK
Indonesia merupakan pasar otomotif terbesar di ASEAN, hal ini ditunjukkan dengan penjualan mobil dan motor tertinggi di ASEAN periode 2014-2019. Selain itu, ekspor mobil dan motor di Indonesia memiliki tren yang meningkat. Hal ini menyebabkan perusahaan manufaktur sub-sektor otomotif dan produk komponen mengalami pertumbuhan aset yang cepat setiap tahunnya, karena setiap perusahaan terus mengembangkan produksinya. Setiap perusahaan dalam mengembangkan bisnis tidak hanya membutuhkan pendanaan internal tetapi juga pendanaan eksternal dengan melakukan pinjaman utang melalui kreditur. Perusahaan lebih memilih utang karena memiliki biaya relatif kecil dibandingkan dengan mengeluarkan emisi saham baru meskipun resiko yang dihadapi lebih besar. Peminjaman utang dapat menimbulkan adanya biaya utang pada sebuah perusahaan. Penelitian ini memiliki tujuan untuk menganalisis biaya utang serta mengkaji determinan biaya utang perusahaan manufaktur sub sektor otomotif dan produk komponen yang terdaftar di Bursa Efek Indonesia tahun 2014-2019. Metode penelitian yang digunakan yaitu fixed effect model dengan cross sectional weight. Menurut hasil penelitian bisa disimpulkan variabel debt to equity ratio memiliki pengaruh positif serta signifikan terhadap biaya utang. Sebaliknya, variabel return on asset, ukuran perusahaan, dan current ratio memiliki pengaruh negatif serta signifikan terhadap biaya utang.
\end{abstract}

Kata kunci: biaya utang, perusahaan manufaktur, otomotif dan produk komponen, fixed effect model dengan cross sectional weight

\begin{abstract}
Indonesia is the largest automotive market in ASEAN, this is indicated by the highest car and motorcycle sales in ASEAN for the 2014-2019 period. In addition, exports of cars and motorcycles in Indonesia have an increasing trend. This causes manufacturing companies in the automotive and component product sub-sectors to experience rapid asset growth every year, because each company continues to develop its production. Every company in developing its business requires not only internal funding but also external funding by making debt loans through creditors. Companies prefer debt because it has a relatively small cost compared to issuing new shares even though the risks faced are greater. Borrowing debt can incur cost of debt in a company. This study has a purpose to analyze the cost of debt and examine the determinants of the cost of debt of manufacturing companies in the automotive and component products sub-sector listed on the Indonesia Stock Exchange in 2014 to 2019. The research method used is a fixed effect model with cross sectional weight. According to the research results can be concluded variable debt to equity ratio has a positive influence and significant to the cost of debt. On the other hand, the return on assets, firm size, and current ratio variables have a negative influence and significant to the cost of debt.
\end{abstract}

Keywords: cost of debt, manufacturing companies, automotive and component products, fixed effect model with crosssectional weight

\section{PENDAHULUAN}

Industri otomotif dan produk komponen adalah suatu perusahaan yang beranjak di bidang otomotif dan pemasok sparepart perbaikan kendaraan bermotor (Brigham dan Houston, 2011). Kementerian Perindustrian (2018) memutuskan terdapat lima sektor manufaktur menurut "Making Industri 4.0" yang hendak diprioritaskan pengembangannya di tahap awal supaya menjadi percontohan dalam implementasi revolusi industri generasi keempat di negara Indonesia. Kelima sektor tersebut ialah industri otomotif, makanan dan minuman, elektronika, kimia serta industri tekstil dan pakaian. Kelima sektor tersebut dapat berkontribusi 65 persen terhadap total ekspor, berkontribusi sebesar 60 persen untuk Produk Domestik Bruto seta 60 persen tenaga kerja industri terdapat di lima sektor industri tersebut. Oleh karena itu, Kementerian Perindustrian berfokus pada peningkatan daya saing pada lima sektor industri tersebut. Untuk sektor industri otomotif, 
negara Indonesia dapat menjadi pasar otomotif terkemuka dalam ekspor kendaraan. Indonesia merupakan salah satu negara tertinggi dalam penjualan mobil dan sepeda motor di ASEAN Tahun 2014-2019. Penjualan mobil dan motor di Indonesia yang tinggi pada tahun 2014-2019 selain didorong oleh daya beli masyarakat Indonesia juga didukung oleh ekspor mobil Completely Built Up (CBU) dan motor yang memiliki tren meningkat dari tahun 2014-2019. Hal ini menjadikan negara Indonesia sebagai pasar otomotif terbesar di ASEAN. Persaingan pasar industri otomotif sangat ketat untuk memperoleh pangsa pasar, sehingga membuat setiap perusahaan terus mengembangkan produksinya maka dari itu perusahaan sektor otomotif dan produk komponen menjadi salah satu sub sektor yang menjanjikan untuk berkembang di Indonesia.

Produsen otomotif dan produk komponen dunia saling bersaing dalam menciptakan produk yang sesuai dengan selera pasar dan dapat memengaruhi keputusan yang diambil oleh konsumen. Produksi mobil dan motor di negara Indonesia tersebut dapat menjadi potensi dalam penjualan produk komponen. Kementerian Perindustrian (2019) melalui pengembangan industri komponen di Indonesia termasuk pada sektor industri kecil dan menengah akan terus memacu pertumbuhan serta daya saing industri otomotif nasional. Hal ini dikarenakan, industri komponen masih mempunyai pangsa pasar yang sangat luas baik domestik dan juga ekspor, serta memiliki peluang untuk terus mengembangkan teknologi industri komponen sehingga dapat bersaing di pasar global.

Perusahaan manufaktur pada sub sektor otomotif dan produk komponen dapat menjadi alternatif investasi karena mengalami pertumbuhan aset perusahaan yang cepat setiap tahun. Menurut data realisasi investasi berdasarkan sektor dari Badan Koordinasi Penanaman Modal (BKPM) bahwa sektor industri kendaraan bermotor dan alat transportasi lain tahun 2014 berada pada peringkat keenam penanaman modal asing yaitu sebesar 2.061.275,92 ribu US\$ atau sebesar 7,23 persen dari total penanaman modal asing. Namun, penanaman modal dalam negeri pada sektor industri kendaraan bermotor dan alat transportasi lain tahun 2014 lebih rendah dari penanaman modal asing yaitu sebesar 490.094,06 juta rupiah atau sebesar 0,31 persen dari total penanaman modal dalam negeri. Sementara itu, pada tahun 2019 penanaman modal asing sektor industri kendaraan bermotor dan alat transportasi lain menurun menjadi sebesar 497.163,81 ribu US $\$$ atau sebesar 2,35 persen dari total penanaman modal asing, namun nilai investasi penanaman modal asing tetap lebih tinggi dibandingkan penanaman modal dalam negeri pada tahun 2019. Disisi lain, penanaman modal dalam negeri sektor industri kendaraan bermotor dan alat transportasi lain tahun 2019 meningkat dibandingkan tahun 2014 yaitu sebesar 923.539,43 juta rupiah atau sebesar 0,32 persen dari total penanaman modal dalam negeri. Tingginya penanaman modal asing maupun penanaman modal dalam negeri pada sektor industri kendaraan bermotor dan alat transportasi lain dapat dijadikan gambaran bahwa investor maupun kreditur tertarik untuk menjadi pemodal bagi perusahaan otomotif dan produk komponen yang membutuhkan pendanaan eksternal baik dari asing maupun dalam negeri.

Babu dan Jain (1998) menyatakan bahwa terdapat empat keterangan penyebab perusahaan lebih memilih menerbitkan surat utang daripada saham baru, yakni terdapat utilitas pajak atas pembayaran bunga, biaya transaksi emisi saham baru lebih mahal daripada biaya transaksi pengeluaran utang, pendanaan saham lebih sulit didapatkan daripada pendanaan utang, serta kontrol manajemen perusahaan lebih besar apabila terdapat utang baru daripada terdapat saham baru. Perusahaan yang tengah berkembang memerlukan modal yang berasal dari utang (Brigham dan Hauston, 2011).

Sebuah perusahaan pastinya tidak akan pernah lepas dari masalah pendanaan. Perusahaan akan menerbitkan surat utang ketika membutuhkan pendanaan eksternal agar dibeli oleh para kreditur. Sehingga kreditur akan mendapatkan imbalan berupa bunga ketika membeli surat utang. Pengembalian utang perusahaan kepada para kreditur itulah yang nantinya jadi biaya utang (cost of debt) berupa tingkat bunga bagi sebuah perusahaan. Biaya utang menurut Fabozzi (2007) yakni tingkat bunga pengembalian yang diharapkan oleh kreditur ketika meminjamkan utang kepada perusahaan.

Berdasarkan data Bank Dunia melalui laporan International Debt Statistics (IDS), pada tahun 2019 negara Indonesia ada diposisi ketujuh dari sepuluh negara yang memiliki pendapatan kecil hingga menengah dengan jumlah utang luar negeri tertinggi. Jumlah nilai utang tersebut termasuk utang luar negeri pemerintah, BUMN, bahkan swasta. Maka dari itu, negara Indonesia memiliki akses yang lebih baik untuk memasuki pendanaan eksternal. Sehingga perusahaan swasta di Indonesia condong untuk memilih memakai pendanaan eksternal yaitu menggunakan pinjaman dari kreditur. Sebelum perusahaan memilih pendanaan internal dan pendanaan eksternal, perusahaan tentu mempertimbangkan terlebih dahulu beberapa faktor yang dapat memengaruhi tingginya biaya utang perusahaan. Hal ini ditujukan agar perusahaan tidak mengalami penundaan pembayaran utang kepada kreditur yang dapat menyebabkan biaya utang semakin tinggi.

Menurut data Badan Pusat Statistik (BPS), sejak tahun 2014 ke tahun 2019 kontribusi pada sektor otomotif terhadap Produk Domestik Bruto non migas memiliki tren yang menurun. Kontribusi sektor otomotif terhadap PDB non migas pada tahun 2019 yaitu sebesar 9,28 persen lebih rendah dibandingkan pada tahun 
2014 sebesar 10,97 persen. Selain itu, berdasarkan data ASEAN Automotive Federation total penjualan mobil dan motor Indonesia pada tahun 2019 sebesar 7.517.586 unit lebih rendah dibandingkan tahun 2014 sebesar 9.116.960 unit, bahkan penjualannya jauh dibawah total produksi mobil dan motor pada tahun 2019 sebesar 8.584.496 unit. Kedua hal ini dapat menjadi masalah jika kontribusi sektor otomotif dan total penjualan mobil dan motor menurun pada tahun 2019, namun biaya utang perusahaan meningkat. Sehingga, peneliti ingin meneliti faktor-faktor yang diduga memengaruhi biaya utang (cost of debt) pada perusahaan manufaktur sub sektor otomotif dan produk komponen yang terdaftar di Bursa Efek Indonesia (BEI) periode 2014-2019. Faktor-faktor yang diduga tersebut adalah rasio operating cash flow ratio, debt to equity ratio, net profit margin, return on asset, ukuran perusahaan, dan current ratio.

Perusahaan mampu untuk membayar utangnya ketika memiliki operating cash flow ratio yang tinggi (Petersen dan Rajan, 1994). Sehingga tidak terjadi gagal bayar utang yang dapat menyebabkan biaya utang semakin tinggi. Kemudian, debt to equity ratio dapat menunjukkan tingkat pendanaan perusahaan yang dibiayai oleh utang dibandingkan dengan yang pendanaan oleh para pemegang saham. Menurut Yudarrudin et al. (2017), semakin besar debt to equity ratio maka semakin besar modal pinjaman sehingga akan menyebabkan semakin besar pula biaya utang yang harus ditanggung perusahaan. Selanjutnya net profit margin merupakan salah satu rasio profitabilitas yang diukur dengan membandingkan laba bersih dengan total penjualan. Diamond dan Verrecchia (1991) membuktikan bahwa profitabilitas memengaruhi hubungan pengungkapan laporan keuangan dengan biaya modal, maka perusahaan yang memiliki profitabilitas yang tinggi selalu mengungkapkan informasi laporan keuangan dan cenderung memiliki biaya modal yang rendah. Dengan demikian, perusahaan yang memiliki profitabilitas yang tinggi dipercaya oleh para investor dan kreditur. Sehingga hal tersebut dapat menurunkan biaya utang perusahaan. Selain itu, hasil pengukuran return on asset yang juga merupakan salah satu rasio profitabilitas sering digunakan untuk mengukur kinerja keuangan suatu perusahaan. Semakin besar nilai return on asset suatu perusahaan maka semakin besar pula tingkat keuntungan yang diperoleh perusahaan dan juga posisi perusahaan dalam hal penggunaan aset, sehingga dapat mengurangi biaya utang (Dirman, 2020). Lalu, biaya utang dan ukuran perusahaan memiliki hubungan yang terbalik, yang diukur sebagai logaritma natural dari total aset, karena kreditur menganggap perusahaan besar kurang berisiko dan ada skala ekonomi dalam biaya produksi menggunakan utang (Carey et al., 1993). Berikutnya, current ratio merupakan salah satu rasio likuiditas. Menurut Dirman (2020), semakin likuid perusahaan maka semakin rendah pula biaya utang yang harus dibayar oleh perusahaan.

Dirman (2020) menyatakan dengan metode regresi linier berganda bahwa faktor yang memengaruhi biaya utang perusahaan manufaktur sektor industri dasar dan kimia yang tercatat di Bursa Efek Indonesia tahun 2016-2019 adalah leverage yang memberikan pengaruh positif dan signifikan. Selain itu, Sherly dan Fitria (2019) menyatakan dengan metode regresi linier berganda bahwa faktor yang memengaruhi biaya utang perusahaan manufaktur yang tercata di Bursa Efek Indonesia pada tahun 2011-2015 adalah penghindaran pajak dan profitabilitas yang memberikan pengaruh negatif dan signifikan. Adapun penelitian lain dari Utama, Kirana, dan Sitanggang (2019) menyatakan dengan metode regresi linier berganda bahwa faktor yang memengaruhi biaya utang perusahaan manufaktur yang tercatat di Bursa Efek Indonesia tahun 2015-2017 pada persamaan 1 adalah ukuran perusahaan dan leverage yang memberikan pengaruh positif dan signifikan, sedangkan pada persamaan 2 yaitu leverage, umur perusahaan, dan ukuran perusahaan yang memberikan pengaruh negatif dan signifikan. Kemudian ada penelitian lainnya yang diteliti oleh Narita (2012) yang menggunakan metode regresi linier berganda bahwa faktor yang memengaruhi kebijakan utang pada perusahaan manufaktur yang tercatat di Bursa Efek Indonesia tahun 2019-2010 yakni profitabilitas dan likuiditas yang memberikan pengaruh negatif dan signifikan terhadap kebijakan utang.

\section{METODE}

\section{Biaya Utang}

Biaya utang (cost of debt) ialah besarnya tingkat bunga yang wajib dibayar oleh perusahaan atas utangnya. Definisi biaya utang yaitu tingkat bunga utang sebuah perusahaan yang diukur sebagai biaya bunga untuk tahun tersebut dibagi dengan rata-rata utang jangka pendek dan jangka panjang selama tahun tersebut (Pittman dan Fortin, 2004). Karakteristik perusahaan dan perusahaan yang menerbitkan obligasi akan menyebabkan risiko gagal bayar, biaya agensi, dan masalah asimetri informasi yang dapat menentukan biaya utang perusahaan (Bhojraj dan Sengupta, 2003). Kriteria yang menunjukkan gagal bayar pada perusahaan yaitu ketika total aset lancar yang dimiliki perusahaan lebih kecil dibandingkan utang lancar perusahaan. 


$$
\text { Cost of Debt }=\frac{\text { Beban Bunga }}{\begin{array}{c}
\text { Jumlah Rata }- \text { Rata Utang Jangka } \\
\text { Pendek dan Jangka Panjang }
\end{array}} \times 100 \%
$$

\section{Operating Cash Flow Ratio}

Menurut PSAK No. 2 (2015) dari aktivitas penghasil utama pendapatan perusahaan dapat memperoleh arus kas dari aktivitas operasi. Arus kas operasi yang digambarkan dalam laporan arus kas juga mencakup kas dari aktivitas investasi dan pendanaan. Operating cash flow ratio bisa menyampaikan ilustrasi yang lebih lengkap mengenai kemampuan perusahaan untuk melunasi kewajiban utang menggunakan arus kas operasi. Operating cash flow ratio secara matematis yaitu membagi arus kas operasi dengan rata-rata utang jangka pendek (Zeller dan Stanko, 2011). Operating cash flow ratio dikatakan baik apabila lebih dari 1.

$$
\text { Operating Cash Flow Ratio }=\frac{\text { Arus Kas Operasi }}{\text { Rata }- \text { Rata Utang Jangka Pendek }}
$$

\section{Debt to Equity Ratio}

Debt to equity ratio adalah perbandingan utang dan ekuitas dalam penyediaan dana perusahaan dan membuktikan kemampuan perusahaan tersebut dalam melunasi semua kewajibannya (Sawir, 2009). Debt to equity ratio secara matematis yaitu total utang dibagi dengan total ekuitas pemegang saham (Horne dan Wachowicz, 2012). Debt to equity ratio dikatakan baik apabila nilainya dibawah 1.

$$
\text { Debt to Equity Ratio }=\frac{\text { Total Utang }}{\text { Total Ekuitas }}
$$

\section{Net Profit Margin}

Net Profit Margin termasuk ke dalam rasio profitabilitas dengan membandingkan laba bersih dengan penjualan perusahaan, selain itu dapat diartikan tingkat kemampuan perusahaan menghemat biaya operasional yang dikeluarkan dalam suatu periode tertentu (Sutrisno, 2013). Apabila net profit margin mencapai 3,92 persen atau lebih, maka net profit margin dapat dikatakan baik (Lukviarman, 2006). Secara matematis net profit margin dihiutng dengan membandingkan antara laba bersih dengan penjualan bersih perusahaan (Janice dan Toni, 2020).

$$
\text { Net Profit Margin }=\frac{\text { Laba Bersih }}{\text { Penjualan Bersih }} \times 100 \%
$$

\section{Return on Asset}

Return on asset termasuk juga ke dalam rasio profitabilitas yang menunjukkan pengembalian berdasarkan jumlah aktiva yang dipakai oleh perusahaan (Kasmir, 2014). Return on asset sering digunakan investor dan kreditur untuk menilai hasil kinerja manajemen suatu perusahaan secara keseluruhan. Seberapa baik kinerja perusahaan ditunjukkan oleh rasio keuangan ini dengan membandingkan antara laba bersih yang dihasilkan dengan modal yang diinvestasikan pada asset perusahaan. Apabila return on asset mencapai nilai 5,98 persen atau lebih, maka return on asset dapat dikatakan baik (Lukviarman, 2006). Menurut Irman dan Purwanti (2020), return on asset dapat dihitung dengan membandingkan laba bersih dengan total aset perusahaan.

$$
\text { Return on Asset }=\frac{\text { Laba Bersih }}{\text { Total Asset }} \times 100 \%
$$

\section{Ukuran Perusahaan}

Ukuran perusahaan yaitu petunjuk yang dipakai kreditur dan investor untuk mengukur kinerja perusahaan dan aset perusahaan. Besar kecilnya sebuah perusahaan dapat digambarkan melalui ukuran perusahaan. Ukuran dari besarnya total aset yang dimiliki oleh perusahaan merupakan ukuran perusahaan. Semakin besar total aset sebuah perusahaan maka akan meningkatkan kepercayaan kreditur untuk memberikan pinjaman kepada perusahaan (Awaloedin dan Nugroho, 2019). Karena ketika pinjaman telah jatuh tempo maka perusahaan besar mempunyai jaminan aset yang lebih besar dibandingkan perusahaan kecil. Ukuran perusahaan, diukur sebagai logaritma natural dari total aset (Francis et al., 2005).

$$
\text { Ukuran Perusahaan }=\operatorname{Ln}(\text { Total } \text { Asset })
$$




\section{Current Ratio}

Current Ratio merupakan perbandingan untuk menilai kemampuan sebuah perusahaan saat melunasi kewajiban utang jangka pendek atau utang yang segera jatuh tempo ketika diminta seluruhnya (Kasmir, 2014). Perusahaan cenderung memakai dana yang berasal dari internal dibandingkan dana yang berasal dari eksternal untuk kegiatan operasional perusahaan ketika nilai current ratio perusahaan tersebut tinggi. Perusahaan dapat memenuhi kewajibannya ketika pemakaian dana perusahaan itu sendiri lebih besar dibandingkan pemakaian utang (Siregar dan Fahmi, 2018). Sehingga perusahaan tersebut dapat lebih dipercaya oleh kreditur karena perusahaan sanggup melunasi kewajiban utangnya. Perusahaan akan lebih mudah mendapatkan pinjaman utang karena telah mendapatkan kepercayaan dari kreditur. Perusahaan mempunyai kemampuan yang baik dalam melunasi utang jangka pendek apabila current ratio sebuah perusahaan lebih besar dari 1 . Menurut Irman dan Purwanti (2020), perhitungan current ratio menggunakan rumus berikut ini.

$$
\text { Current Ratio }=\frac{\text { Aset lancar }}{\text { utang lancar }}
$$

\section{Model Persamaan Regresi Data Panel}

Tahapan yang dikerjakan ketika melakukan analisis regresi data panel yaitu menguji stasioneritas data setiap variabel, memilih model terbaik (uji chow, hausman, dan BP-LM), memeriksa struktur matriks varianskovarians residual, pemeriksaan uji asumsi klasik dan keberartian model, serta melakukan interpretasi terhadap model. Penelitian ini menggunakan model umum regresi data panel sebagai berikut:

$$
\begin{gathered}
C O D_{i t}=\alpha_{0}+\beta_{1} O C F_{i t}+\beta_{2} D E R_{i t}+\beta_{3} N P M_{i t}+\beta_{4} R O A_{i t}+\beta_{5} S I Z E_{i t}+\beta_{6} C R_{i t}+\varepsilon_{i t} \\
\varepsilon_{i t}=\gamma_{i}+u_{i t} \text { dimana } \gamma_{i}=\text { fixed, random, atau common }=0
\end{gathered}
$$

Keterangan:

$C O D_{i t} \quad$ : biaya utang (cost of debt) setiap individu ke-i dan periode waktu ke-t

$O C F_{i t} \quad$ : operating cash flow ratio setiap individu ke-i dan periode waktu ke-t

$D E R_{i t} \quad$ : debt to equity ratio setiap individu ke-i pada periode waktu ke-t

$N P M_{i t} \quad:$ net profit margin setiap individu ke-i pada periode waktu ke-t

$R O A_{i t} \quad$ : return on asset setiap individu ke-i pada periode waktu ke-t

$S I Z E_{i t} \quad$ : ukuran perusahaan setiap individu ke-i pada periode waktu ke-t

$C R_{i t} \quad:$ current ratio setiap individu ke-i pada periode waktu ke-t

$\varepsilon_{i t} \quad:$ komponen error setiap individu ke-i pada periode waktu ke-t

$i \quad:$ individu (perusahaan manufaktur sub sektor otomotif dan produk komponen)

$t \quad: 2014, \ldots ., 2019$

\section{Data dan Sumber Data}

Penelitian ini menggunakan data sekunder yang didapatkan dari situs web Bursa Efek Indonesia dan publikasi laporan keuangan tahunan dari masing-masing perusahaan manufaktur sub sektor otomotif dan produk komponen. Daftar perusahaan manufaktur seb sektor otomotif dan produk komponen didapatkan dari situs web Bursa Efek Indonesia. Sedangkan data laporan keuangan masing-masing perusahaan yang didapatkan berasal dari publikasi laporan keuangan tahun 2014-2019 dengan mengunduh laporan keuangan tersebut dari situs web masing masing perusahaan manufaktur sub sektor otomotif dan produk komponen tanpa meminta perizinan. Selain itu, data yang digunakan tidak dilakukan transformasi.

Metode yang dipakai untuk menentukan sampel dalam penelitian ini yaitu purposive sampling. Sehingga, sampel dipilih menurut kriteria karakteristik yang ditentukan. Berikut ini merupakan kriteria karakteristik dalam menentukan sampel:

1. Perusahaan manufaktur sub sektor otomotif dan produk komponen tercatat pada Bursa Efek Indonesia.

2. Perusahaan manufaktur sub sektor otomotif dan produk komponen memiliki laporan keuangan tahunan yang jangkap dari tahun 2014-2019.

3. Perusahaan manufaktur sub sektor otomotif dan produk komponen tidak di suspend dan delisting dari Bursa Efek Indonesia (BEI).

Penelitian ini menggunakan variabel dependen yaitu biaya utang. Sementara itu, variabel independen yang diduga berpengaruh terhadap biaya utang yaitu operating cash flow ratio, debt to equity ratio, net profit margin, return on asset, ukuran perusahaan, dan current ratio. 


\section{HASIL DAN PEMBAHASAN}

\section{Perkembangan Biaya Utang Perusahaan Manufaktur Sub Sektor Otomotif dan Produk Komponen yang Terdaftar di BEI Tahun 2014-2019}

Berdasarkan perkembangan biaya utang setiap perusahaan manufaktur sub sektor otomotif dan produk komponen mengalami fluktuasi. Perusahaan yang memiliki biaya utang tertinggi yaitu PT. Multi Prima Sejahtera Tbk (LPIN) di tahun 2017 yaitu sebesar 46,27 persen. Kondisi ini dikarenakan pada tahun 2015 perusahaan LPIN memulai bisnis coffee shop yaitu max coffee dan pada tahun 2017 ditargetkan mengelola 150 gerai max coffee. Sehingga pada tahun 2017 perusahaan ini membutuhkan dana yang besar tidak hanya dana internal namun juga dana eksternal untuk melakukan ekspansi bisnis di bidang tersebut. Maka dari itu, nilai biaya utang perusahaan LPIN tahun 2017 tinggi karena memiliki beban utang yang tinggi. Sedangkan biaya utang (cost of debt) terendah juga diperoleh PT. Multi Prima Sejahtera Tbk (LPIN) di tahun 2019 sebesar 0,07 persen. Hal ini dikarenakan terjadinya penurunan utang perusahaan LPIN pada tahun 2019 sehingga beban bunga perusahaan pun ikut menurun.

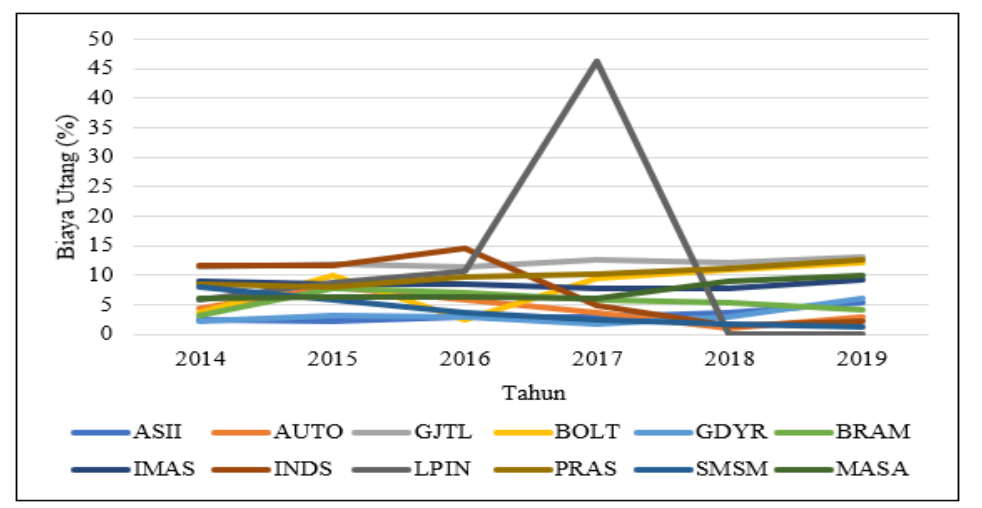

Sumber: Laporan Tahunan Keuangan Perusahaan Tahun 2014-2019 (diolah)

Gambar 1. Biaya utang perusahaan otomotif dan produk komponen periode 2014-2019

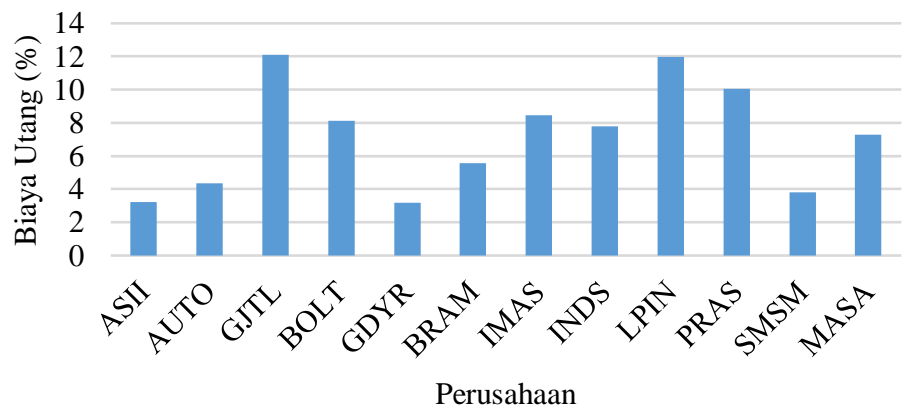

Sumber: Laporan Tahunan Keuangan Perusahaan Tahun 2014-2019 (diolah)

Gambar 2. Rata-rata biaya utang perusahaan otomotif dan produk komponen tahun 2014-2019

Rata-rata biaya utang dapat dilihat pada Gambar 2, dimana biaya utang tertinggi dari masing-masing perusahaan manufaktur otomotif dan produk komponen selama lima tahun yaitu perusahaan PT. Gajah Tunggal Tbk (GJTL) yaitu sebesar 12,1 persen. PT. Gajah Tunggal Tbk (GJTL) memiliki nilai rata-rata biaya utang tinggi karena setiap tahun mendapat persetujuan pemegang saham untuk menerbitkan surat utang yang digunakan untuk mempercepat pembayaran utang lama yang telah jatuh tempo setiap tahunnya. Hal ini dinilai dapat menguntungkan bagi perusahaan GJTL, karena jatuh tempo pembayaran utang perusahaan akan semakin panjang. Sehingga likuiditas perusahaan GJTL akan tetap terjaga. Selain itu, dana dari hasil penjualan surat utang yang diterbitkan oleh perusahaan GJTL digunakan untuk melakukan ekspansi bisnis dalam pembuatan produk baru. Hal ini dilakukan untuk memperbesar pasar perusahaan GJTL sehingga pendapatan perusahaan meningkat setiap tahunnya. Sedangkan rata-rata biaya utang terendah dari tiap-tiap perusahaan manufaktur sub sektor otomotif dan produk komponen selama lima tahun yaitu PT. Goodyear Indonesia Tbk (GDYR) yaitu sebesar 3,17 persen. PT. Goodyear Indonesia Tbk (GDYR) memiliki nilai rata-rata biaya utang yang rendah karena perusahaan selalu meminimalisasi utang, tetapi tetap dapat mencetak laba perusahaan yang positif. 


\section{Estimasi Model Persamaan Regresi Data Panel}

Pengujian stasioneritas pada masing-masing variabel dilakukan terlebih dahulu sebelum melakukan analisis regresi data panel. Didapatkan bahwa keenam variabel stasioner di level dengan tingkat signifikansi 5 persen. Selanjutnya dilakukan pemilihan model terbaik. Pertama dilakukan uji chow yang menghasilkan nilai probability sebesar 0,0000 maka tolak $\mathrm{H}_{0}$, yang artinya fixed effect model lebih baik dibandingkan common effect model. Kemudian dilanjutkan dengan uji hausman yang menghasilkan nilai probability 0,0393 sehingga tolak $\mathrm{H}_{0}$, yang artinya fixed effect model lebih baik dibandingkan random effect model. Akhirnya model terbaik yang terpilih adalah fixed effect model.

Kemudian, perlu dilakukan pengujian struktur matriks varians-kovarians residual. Pertama dilakukan uji LM yang mendapatkan hasil pengujian sebesar 22,0216 yang mana nilainya lebih besar dibandingkan nilai kritis $\chi_{(0,05 ; 11)}^{2}$ sebesar 19,6751 sehingga tolak $\mathrm{H}_{0}$, yang artinya struktur matriks varians-kovarians residual bersifat heteroskedastisitas. Sehingga selanjutnya perlu dilakukan uji $\lambda_{L M}$. Berdasarkan hasil perhitungan dari pengujian statistik $\lambda_{L M}$ diperoleh nilai statistik uji $\lambda_{L M}$ adalah sebesar 85,7969 yang mana nilainya lebih kecil dibandingkan nilai kritis $\chi_{(0,05 ; 66)}$ sebesar 85,9649 sehingga gagal tolak $\mathrm{H}_{0}$, yang artinya struktur matriks varians-kovarians residual memiliki sifat heteroskedastisitas dan tidak terdapat cross-sectional correlation. Dengan demikian, model yang tepat dipakai ialah fixed effect model dengan metode estimasi cross sectional Weight.

Penelitian ini menggunakan hipotesis satu arah yang diuji menggunakan uji t. Sehingga hasil estimasi persamaan biaya utang dengan metode analisis regresi data panel dapat dituliskan dibawah ini.

$$
\begin{aligned}
\widehat{C O D}_{i t}= & \left(109,4078+\hat{\gamma}_{i}\right)+1,3400 \text { OCF }_{i t}+1,8279 \mathrm{DER}_{i t}{ }^{*}{ }^{*}+0,3732 \mathrm{NPM}_{i t} \\
& -0,3862 \mathrm{ROA}_{i t}{ }^{*}-3,4512 \operatorname{SIZE}_{i t}{ }^{*}-1,8097 \mathrm{CR}_{i t}{ }^{*}
\end{aligned}
$$

Keterangan: $* \quad$ : signifikan pada taraf signifikansi 5 persen

$$
\gamma_{i} \quad \text { : efek individu ke-i }
$$

Tabel 1. Hasil estimasi fixed effect model persamaan biaya utang dengan metode estimasi WLS

\begin{tabular}{ccccccc}
\hline Variabel & Coefficient & Std. Error & t-statistic & Prob. & $t_{(0,05 ; 54)}$ & Kesimpulan \\
\hline C & 109,4078 & 24,0263 & 4,5537 & 0,0000 & - & - \\
OCF & 1,3400 & 1,1248 & 1,1808 & 0,2428 & -1.6736 & Tidak Signifikan \\
DER & 1,8279 & 0,4200 & 4,3521 & 0,0001 & 1.6736 & Signifikan \\
NPM & 0,3732 & 0,0896 & 4,1658 & 0,0001 & -1.6736 & Tidak Signifikan \\
ROA & $-0,3862$ & 0,2263 & $-1,7062$ & 0,0937 & -1.6736 & Signifikan \\
SIZE & $-3,4512$ & 0,8301 & $-4,1574$ & 0,0001 & -1.6736 & Signifikan \\
CR & $-1,8097$ & 0,3259 & $-5,5520$ & 0,0000 & -1.6736 & Signifikan \\
& $R$-squared & & & 0,9106 & \\
& Adj - -Squared & & & 0,8825 & \\
& $F$-statistic & & & 32,3782 & \\
& Prob F-Statistic $)$ & & & 0,0000 & \\
\hline
\end{tabular}

Selanjutnya diperlukan pengujian asumsi klasik pada model tersebut. Menurut Gujarati dan Porter (2008) metode estimasi menggunakan Generalized Least Square (GLS) dapat mengakomodasi asumsi homoskedastisitas dan non autokorelasi di dalam model. Sehingga pengujian asumsi klasik normalitas dan non multikolinearitas saja yang dilakukan. Pengujian normalitas dilakukan menggunakan uji Jarque-Bera yang menghasilkan nilai probability sebesar 0,8283 yang menunjukkan bahwa residual berdistribusi normal. Sedangkan uji multikolinearitas dilakukan dengan melihat besarnya nilai VIF, yang mana menunjukkan seluruh variabel independen memiliki nilai $\mathrm{VIF}<10$, maka asumsi non multikolinearitas terpenuhi yaitu tidak terdapat multikolinearitas antara variabel independen yang digunakan.

Setelah melakukan uji asumsi klasik, perlu melakukan pengujian keberartian model dengan melihat nilai adj $R^{2}$, uji F, dan uji t pada model. Diperoleh nilai adj $R^{2}$ sebesar 0,8825 artinya keenam variabel independen dapat menjelaskan variasi dari biaya utang perusahaan manufaktur sub sektor otomotif dan produk komponen sebesar 88,25 persen. Sedangkan sebesar 11,75 persen sisanya, variasi dari biaya utang perusahaan manufaktur sub sektor otomotif dan produk komponen yang diuraikan oleh faktor lain yang tidak diteliti pada model tersebut. Kemudian, diperoleh nilai prob. F-statistic sebesar 0,0000 yang mana lebih kecil dari taraf signifikansi 5 persen maka tolak $\mathrm{H}_{0}$, artinya paling tidak terdapat satu variabel independen yang memengaruhi atau signifikan terhadap variabel dependen yaitu biaya utang perusahaan manufaktur sub sektor otomotif dan produk komponen. Oleh karena itu perlu melakukan uji t untuk melihat variabel independen yang signifikan pada model. Diketahui bahwa variabel independen yang memengaruhi model secara signifikan adalah debt to equity ratio, return on asset, ukuran perusahaan, dan current ratio. 


\section{Pengaruh Operating Cash Flow Ratio terhadap Biaya Utang}

Berdasarkan hasil estimasi model yang diperoleh, dapat dilihat bahwa operating cash flow ratio tidak berpengaruh signifikan terhadap biaya utang perusahaan manufaktur sub sektor otomotif dan produk komponen. Hubungan tersebut tidak cocok dengan hipotesis penelitian. Hipotesis yang tidak cocok tersebut searah dengan penelitian yang diteliti oleh Utama, Kirana, dan Sitanggang (2019) bahwa menurut hasil analisis regresi linier berganda yang sudah dilakukan pada persamaan 1 dan 2, variabel operating cash flow ratio tidak berpengaruh signifikan terhadap biaya utang. Kondisi ini disebabkan oleh nilai operating cash flow ratio sebuah perusahaan yang tinggi belum tentu mempunyai biaya utang perusahaan yang rendah.

\section{Pengaruh Debt to Equity Ratio terhadap Biaya Utang}

Hasil penelitian ini menyatakan bahwa, variabel debt to equity ratio memiliki pengaruh positif dan signifikan terhadap biaya utang perusahaan manufaktur sub sektor otomotif dan produk komponen. Penggunaan variabel debt to equity ratio atau disebut juga leverage sesuai dengan teori dan literatur sebelumnya. Menurut teori Agensi, selalu terdapat risiko antara perusahaan dengan pihak ketiga atau kreditur. Ketika nilai debt to equity ratio semakin besar maka modal pinjaman juga semakin besar, sehingga mengakibatkan perusahaan akan menanggung biaya utang yang semakin besar (Yudarrudin et al., 2017). Hasil penelitian ini ditunjang oleh penelitian sebelumya yang diteliti oleh Dirman pada tahun 2020 yang berjudul "Cost of Debt: The Impact of Financial Factors and Non-Financial Factors". Hasil penelitian memakai metode analisis regresi linier berganda yang membukikan bahwa variabel leverage yang diproksikan dengan debt to equity ratio berpengaruh positif dan signifikan terhadap biaya utang.

\section{Pengaruh Net Profit Margin terhadap Biaya Utang}

Menurut hasil estimasi model yang diperoleh, dapat dilihat bahwa net profit margin yang merupakan rasio profitabilitas tidak berpengaruh signifikan pada biaya utang perusahaan manufaktur sub sektor otomotif dan produk komponen. Hubungan tersebut tidak cocok dengan hipotesis penelitian. Hipotesis yang tidak cocok tersebut searah dengan analisis yang dilaksanakan oleh Bacha (2019) yang mengatakan bahwa berdasarkan hasil regresi OLS dengan metode estimasi robust standard errors yang telah dilakukan pada variabel profitabilitas tidak berpengaruh signifikan pada biaya utang. Nilai Net profit margin tinggi menandakan semakin tingginya laba dari penjualan perusahaan yang tidak digunakan namun diimbangi dengan peminjaman utang perusahaan yang lebih tinggi dikarenakan perusahaan masih memiliki prospek yang bagus untuk melakukan ekspansi bisnis.

\section{Pengaruh Return on Asset terhadap Biaya Utang}

Hasil analisis regresi data panel membuktikan jika variabel return on asset memiliki pengaruh negatif dan signifikan pada biaya utang perusahaan manufaktur sub sektor otomotif dan produk komponen. Variabel return on asset disebut juga rasio profitabilitas, penggunaan variabel tersebut searah dengan konsep dan literatur sebelumnya. Dimana profitabilitas merupakan faktor yang memengaruhi biaya utang. Perusahaan yang memiliki nilai return on asset yang makin besar maka laba yang diperoleh perusahaan juga makin besar, sehingga dapat mengurangi biaya utang (Dirman, 2020). Hasil dari analisis ini ditunjang oleh penelitian sebelumnya yang diteliti oleh Sherly dan Fitria (2019) yang memiliki judul "Pengaruh Penghindaran Pajak, Kepemilikan Institusional, dan Profitabilitas terhadap Biaya Utang”. Penelitian tersebut menggunakan metode analisis regresi linier berganda yang membuktikan jika variabel profitabilitas yang digantikan dengan return on asset memiliki pengaruh negatif dan signifikan pada biaya utang.

\section{Pengaruh Ukuran Perusahaan terhadap Biaya Utang}

Berdasarkan hasil penelitian menggunakan analisis regresi data panel, variabel ukuran perusahaan memiliki pengaruh negatif dan signifikan pada biaya utang perusahaan manufaktur sub sektor otomotif dan produk komponen. Penggunaan variabel ukuran perusahaan pada studi ini sesuai menurut teori dan literatur sebelumnya. Menurut teori, biaya utang dan ukuran perusahaan memiliki hubungan yang terbalik karena kreditur memandang perusahaan besar memiliki risiko rendah dan terdapat skala ekonomi pada biaya produksi utang (Carey et al., 1993). Hasil analisis ini ditunjang oleh studi sebelumnya yang diteliti oleh Thu et al. (2018) yang berjudul "Perceived audit quality, earnings management and cost of debt capital: Evidence from the energy listed firms on vietnam's stock market". Studi sebelumnya memakai metode analisis regresi data panel yang memiliki hasil penelitian bahwa metode yang dipakai yaitu fixed effect model, dimana pada model 1 dan 2 variabel ukuran perusahaan memiliki pengaruh negatif dan signifikan pada biaya utang.

Pengaruh Current Ratio terhadap Biaya Utang

Menurut hasil analisis regresi data panel yang sudah dianalisis memberikan hasil penelitian yaitu variabel current ratio memiliki pengaruh negatif dan signifikan pada biaya utang. Variabel current ratio yaitu disebut 
rasio likuiditas dalam penelitian ini sesuai dengan teori dan literatur sebelumnya. Menurut teori semakin likuid sebuah perusahaan membuat biaya utang yang harus dibayat oleh perusahaan semakin rendah (Dirman, 2020). Hasil studi ini ditunjang oleh studi sebelumnya yang diteliti oleh Narita (2012) yang berjudul "Analisis Kebijakan Utang". Berdasarkan model regresi, penelitian tersebut membuktikan jika variabel current ratio memiliki pengaruh negatif dan signifikan pada kebijakan utang. Berdasarkan analisis tersebut dapat diketahui apabila kebijakan utang tinggi maka biaya utang perusahaan pun juga tinggi.

\section{KESIMPULAN}

Perkembangan biaya utang setiap perusahaan manufaktur sub sektor otomotif dan produk komponen tahun 2014-2019 yang tercatat di Bursa Efek Indonesia (BEI) mengalami fluktuasi. Fluktuasi tersebut dikarenakan kondisi keuangan masing-masing perusahaan memiliki permasalahan berbeda-beda setiap tahunnya. Berdasarkan keenam variabel yang dipakai penelitian ini, empat diantaranya memberikan pengaruh signifikan terhadap biaya utang perusahaan manufaktur sub sektor otomotif dan produk komponen. Debt to equity ratio memiliki hubungan positif dan signifikan terhadap biaya utang. Sedangkan variabel return on asset, ukuran perusahaan, dan current ratio memiliki hubungan negatif dan signifikan terhadap biaya utang.

\section{DAFTAR PUSTAKA}

Asean Automotive Federation. Asean Automotive Federation Statistics Tahun 2014-2019. 9 Januari 2021. https://www.asean-autofed.com/statistics.html.

Awaloedin, D. T., \& Nugroho, R. (2019). Pengaruh Ukuran Perusahaan Rasio Utang dan Umur Perusahaan terhadap Biaya Utang (Studi pada Perusahaan Manufaktur yang Terdaftar di Bursa Efek Indonesia tahun 2015-2017). Jurnal Rekayasa Informasi, 8(1), 52-69.

Babu, S., dan Jain, P.K. (1998). Empirical Testing of Pecking Order Hypothesis with Reference to Capital Structure Practices in India. Journal of Financial Management \& Analysis. Vol. 11, Issue. 2, P. 63 74.

Badan Koordinasi Penanaman Modal. Data Realisasi Investasi. 23 Juli 2021. https://nswi.bkpm.go.id/.

Badan Pusat Statistik. Produk Domestik Bruto (Lapangan Usaha). 23 Juli 2021. https://www.bps.go.id/indicator/11/65/1/-seri-2010-pdb-seri-2010.html.

Bacha, S. (2019). Corporate Governance Practices and Audit Quality: Do They Matter for the Cost of Debt?. Theoretical Economics Letters, 9(07), 2262.

Baltagi, Badi H. (2005). Econometric Analysis Of Panel Data: Third Edition. Chichester: John Wiley \& Sons Ltd.

Baltagi, Badi H. (2008). Econometric: Fourth Edition. Chichester: Springer.

Bhojraj, S., \& Sengupta, P. (2003). Effect of Corporate Governance on Bond Ratings and Yields: The Role of Institutional Investors and Outside Directors. The journal of Business, 76(3), 455-475.

Brigham, Eugene \& Houston, B. (2011). Dasar-dasar Manajemen Keuangan Edisi 11 Buku 2. Jakarta: Salemba Empat.

Bursa Efek Indonesia. Daftar Saham. 24 Desember 2020. https://www.idx.co.id/.

Carey, M., Prowse, S., Rea, J., Udell, G. (1993). The economics of private placements: a new look. Financial Markets Institutions and Instruments 2.

Dirman, Angela. (2020). Cost of Debt: The Impact of Financial Factors and Non-Financial Factors. Dinasti International Journal of Economics, Finance \& Accounting 1(4): 550-567.

Diamond; D., and R. Verreecchia (1991), Disclosure, Liquidity and the cost of Equity Capital. The Journal of Finance, pp. 1325-1360.

Fabozzi, F. J. (2007). Bond Markets, Analysis, and Strategies (8th ed.). New Jersey: Prentice Hall.

Fahmi, Irham. (2014). Pengantar Manajemen Keuangan (Teori Soal dan Jawab). Bandung: Alfabeta.

Francis, J. R., Khurana, I. K., \& Pereira, R. (2005). Disclosure incentives and effects on cost of capital around the world. The accounting review, 80(4), 1125-1162.

Greene, William H. (2012). Econometric Analysis (7th Ed.). New Jersey: Pearson Education.

Gujarati Damondar N., \& Porter Dawn C. (2008). Basic Econometric: Fifth Edition. New York: McGraw-Hill.

Horne, J. C. V., \& Wachowicz, J. M. (2012). Prinsip-prinsip manajemen keuangan (Dewi Fitriasari dan Deny Kwary, Penerjemah). Jakarta: Salemba Empat.

Ikatan Akuntansi Indonesia. PSAK No. 2 Tentang Laporan Arus Kas- edisi revisi 2015. Penerbit Dewan Standar Akuntansi Keuangan: PT. Raja Grafindo. 
Irman, M., \& Purwati, A. A. (2020). Analysis On The Influence Of Current Ratio, Debt to Equity Ratio and Total Asset Turnover Toward Return On Assets On The Otomotive and Component Company That Has Been Registered In Indonesia Stock Exchange Within 2011-2017. International Journal of Economics Development Research (IJEDR), 1(1), 36-44.

Janice, J., \& Toni, N. (2020). The Effect of Net Profit Margin, Debt to Equity Ratio, and Return on Equity against Company Value in Food and Beverage Manufacturing Sub-sector Companies listed on the Indonesia Stock Exchange. Budapest International Research and Critics Institute (BIRCI-Journal): Humanities and Social Sciences, 3(1), 494-510.

Kasmir. (2014). Analisis Laporan Keuangan (1st Ed.). Jakarta: Rajawali Pers.

Kementerian Industri. (15 Mei 2018). Siaran Pers-Jadi Prioritas Indutri 4.0, Lima Sektor Ini Berkontribusi 60 Persen untuk PDB. 11 Januari 2021. https://kemenperin.go.id/artikel/19231/Jadi-Prioritas-Indutri-4.0,Lima-Sektor-Ini-Berkontribusi-60-Persen-untuk-PDB.

Kementerian Industri. (13 Agustus 2019). Siaran Pers-Industri Komponen Topang Daya Saing Sektor Otomotif Nasional. 11 Januari 2021. https://kemenperin.go.id/artikel/20956/Industri-Komponen-TopangDaya-Saing-Sektor-Otomotif-Nasional.

Lukviarman, N. (2006). Dasar-Dasar Manajemen Keuangan. Padang: Andalas University Pers.

Narita, Rona Mersi. (2012). Analisis kebijakan Utang. Accounting Analysis Journal 1.2.

Pittman, J. A., \& Fortin, S. (2004). Auditor Choice and The Cost of Debt Capital for Newly Public Firms. Journal of Accounting and Economics 37, 113-136.

PT. Astra International Tbk. Laporan Tahunan. 26 Desember 2020. https://www.astra.co.id/.

PT. Astra Otopart Tbk. Laporan Tahunan. 26 Desember 2020. https://www.astra-otoparts.com/.

PT. Gajah Tunggal Tbk. Laporan Tahunan. 26 Desember 2020. http://www.gt-tires.com/indonesia/.

PT. Garuda Metalindo Tbk. Laporan Tahunan. 26 Desember 2020. https://www.garudametalindo.co.id/.

PT. Goodyear Indonesia Tbk. Laporan Tahunan. 26 Desember 2020. https://www.goodyear-indonesia.com/.

PT. Indo Kordsa Tbk. Laporan Tahunan. 26 Desember 2020. http://www.indokordsa.com/.

PT. Indomobil Sukses Internesional Tbk. Laporan Tahunan. 26 Desember 2020. https://www.indomobil.com/our-company.

PT. Indospring Tbk. Laporan Tahunan. 26 Desember 2020. https://www.indospring.co.id/.

PT. Multi Prima Sejahtera Tbk. Laporan Tahunan. 26 Desember 2020. https://multiprimasejahtera.net/.

PT. Prima Alloy Steel Universal Tbk. Laporan Tahunan. 26 Desember 2020. https://www.panther-wheels.net/.

PT. Selamat Sempurna Tbk. Laporan Tahunan. 26 Desember 2020. http://www.smsm.co.id/.

PT. Multistrada Arah Sarana Tbk. Laporan Tahunan. 26 Desember 2020. https://www.multistrada.co.id/.

Sawir, A. (2009). Analisa Kinerja Keuangan dan Perencanaan keauangan Perusahaan, PT. Gramedia Pustaka Utama, Jakarta. Simposium Nasional Akuntansi VI.

Sherly, E. N., \& Fitria, D. (2019). Pengaruh Penghindaran Pajak, Kepemilikan Institusional, dan Profitabilitas terhadap Biaya Utang (Studi Empiris pada Perusahaan Manufaktur yang Terdaftar di BEI Periode 20112015). Ekombis Review: Jurnal Ilmiah Ekonomi dan Bisnis, 7(1), 58-69.

Siregar, Hasrul dan Fahmi, M. (2018). Analisis Struktur Aktiva, Net Profit Margin, dan Current Ratio terhadap Capital Structure pada Perusahaan Go Publik di Bursa Efek Indonesia. Jurnal Manajemen Bisnis STIE IBBI.

Sutrisno. (2013). Manajemen Keuangan Teori, Konsep dan Aplikasi. Yogyakarta: Ekonisia.

Thu, P. A., Khanh, T. H. T., Ha, N. T. T., \& Khuong, N. V. (2018). Perceived audit quality, earnings management and cost of debt capital: Evidence from the energy listed firms on vietnam's stock market. International Journal of Energy Economics and Policy, 8(6), 120-127.

Utama, F., Kirana D. J., dan Sitanggang K. (2019). Pengaruh Penghindaran Pajak terhadap Biaya Utang dan Kepemilikan Institusional sebagai Pemoderasi. Jurnal Bisnis dan Akuntansi, vol. 21, no. 1, pp. 47-60.

Walpole, R. E. (1995). Pengantar Statistika edisi ketiga. Jakarta: Gramedia Pustaka Utama.

Worldbank. 2019. International Debt Statistics. 23 Juli 2021. https://data.worldbank.org/products/ids.

Yudarrudin, R., Defung, F., \& Atmoko, Y. (2017). Pengaruh return on assets, debt to equity ratio, dan firm size terhadap dividend payout ratio.

Zeller, T. L., \& Stanko, B. B. (1994). Operating cash flow ratios measure a retail firms ability to pay. Journal of Applied Business Research (JABR), 10(4), 51-59. 